\title{
Disputes and Solution Mining Business License in The State Administrative Courts
}

\author{
Jeanny H.V Hutauruk \\ Program Doktor Ilmu Hukum \\ Universitas Borobudur \\ Jakarta, Indonesia \\ jeannyhutauruk@yahoo.com
}

\begin{abstract}
Administrative court as one of the executive power also in charge of Justice to examine, decide and resolve disputes State Administration. In the State Administration dispute also known licensing dispute which is also the State Administration dispute, licensing dispute arising in governance will influence the fluency of a clean and credible. Provisions on the Administration dispute state governed by law number 51 of 2009 on the second amendment of Law No. 5 of 1986 regarding administrative courts, while matters concerning the business license of the mine governed by Law No. 4 of 2009 on the Mineral and Coal. In addition to talking about licensing refers to the Law of State Administrative Court also referred to the legislation about to the license.
\end{abstract}

Keywords- mining business license, state administrative courts

\section{INTRODUCTION}

Prior to law number 4 year 2009 pertaining to mineral and coal mining, the dispute settlement between government and investor is settled under Kontrak Karya (KK) or Perjanjian Karya Pengusahaan Pertambangan Batu Bara (PKP2B), where the parties can determine the forum dispute resolution either through national or international arbitration based on the agreement set forth in the agreement. Where the parties may decide the dispute settlement forum through national or international arbitration based on the basis of existing agreement. Meanwhile, the current contract regime has been changing to licensing regime of dispute settlement resolutions based on the provisions of law number 4 year 2009 pertaining to mineral and coal Mining, determines that any dispute appear in operation of Izin Usaha Pertambangan (IUP), Izin Pertambangan Rakyat (IPR) or Izin Usaha Pertambangan Khusus (IUPK) shall be settled by courts and national arbitration with the provisions of state laws and regulations. The transformation of this regime has changed the state equal position in a contract because it serve as a civil law subject became higher in above the regulator of mining company. Meanwhile, in practical field, the license publishing that indeed is Keputusan Tata Usaha Negara (KTUN) may cause public prejudice because there is a strong confusion element. The publishing of KTUN by authority always have a chance of diffusion element for example, in the case of issuing a mining license for a company while at the object location has been issued with another license, as well as the revocation of the license as stipulated in the mining minerals and coal law, the aggrieved party may be able to filed a lawsuit in the state administrative courts, in order that KTUN (granting or revocation of Mining
Business License) is canceled or declared invalid. A lawsuit by a civilian or a legal entity that feels aggrieved has been impaired to the state admin istrative court is to demand that the license had been declared invalid by the judge, so that the decision shall immediately cease exploration and mining activities. The existence of state administrative court in developed countries, especially the welfare state as a milestone for citizens that they have the right to defend themselves have been impaired by the actions of administrative officials because of their decisions. The purpose of the establishment state administrative courts is to provide legal protection for citizens against the actions of admin is trative officials who violate human rights in the field of state administrative law. In addition, the presence of the state administrative courts will provide the same legal protection to adminis trative officials rights accordance with the law. Thus the function of the state administrative courts is first, as a control institution against the actions of administrative officials in order to remain in the legal rails. Secondly, it is a venue to protect the rights of individuals and citizens from unlawful acts committed by administrative officials. As a judicial control institution, the characteristics of state administrative courts are:

1. Supervision with "external control" characteristics because it is an institution that is beyond the power of government.

2. Supervision is emphasis on repressive actions or commonly called "control a posteriori" because it is always done after the occurrence of controlled acts.

3. Supervision is based on the point of "legality", because it only judge from the aspect of law (rechmatigheid) it only.

Administrative officials with their duties will always perform actions, an act of active or passive that can not be separated from the power attached to it because inhaerent or als zodanig in performing duties.The establishment of the state administrative court as the foundation of a society or a citizen to defend their rights impaired by a misconduct of state administration and contrary to the law. The acts of administrative officials are referred as unlawful acts and contrary to the general principles of good governance. Nevertheless analyze the things that the author described above, then the author will examine theoretically whether the above problem is a state administration dispute? And how to resolve the dispute of mining business license under mining law and state administrative law. So in conclusion, the author 
will conduct research with the title "DISPUTE OF MINING OPERATIONS PERMIT AND ITS SETTLEMENT IN THE STATE ADMINISTRATIVE COURT"

\section{RESEARCH QUESTIONS}

The formulation of the problems has been raised in the writing of the thesis is about dispute of mining operations permit and its settlement in the state administrative court. The focus of the study is limited to the following research questions:

1. Does the mining business license is a competence in state adminis trative court?

2. How is the settlement of mining permit dispute in the state adminis trative court?

\section{RESEARCH METHODOLOGY}

This research paper includes in normative research which is also often referred to as doctrinal research with the object or target of research in the form of regulations, legislation and other legal materials. The result of legal research is not to find a new legal theory but to search alternative argument. In this research, conducted in normative juridical that is by examining the subject matter as mentioned above. In addition, the research will also complement it from other relevant aspects based on the scope and identification of the problem formulated.

\section{DISCUSSION}

The state socio-political and legal conditions will determine investors' perceptions in determining their investment decisions. On the other hand, developing countries that are generally not sufficiently strong national economy to move the economy wheels will require foreign investment flows as a trigger. Therefore, that foreign investors tend to demand the stabilization of provisions to be applied to their mining operations is to bind the government as a regulator in certain schemes that guarantee the sustainability of their business, such as tax stability agreements, nail-down provisions and others. However, in the mining and coal law the management of mining is obtained under a license, which is an unilateral administrative legal product that creates both rights and obligations to the holder. The government as the licens or of the authority to regulate the execution of the permit and even revoke it if it is not used properly, at this point investors (especially foreigners) may continue to maintain their wary attitude towards the new mining and coal law landscape as they will face the risk of repeal permit mining at any time by the government. This concern can be understood by looking at several cases of revocation or reduction area in the past by the Governor, Regent or Mayor for various reasons. Moreover, this mineral and coal Act expressly authorizes the regional government to issue or cancel IUPs without being able to intervene by the Central Government in the event of any deviation. The mining and coal law introduces a new system in mining business named a system of cooperation through a licensing mechanis $\mathrm{m}$.

There are several types of permits in this law, there are :

a. Mining Business License (IUP) is a license to carry out mining business, consisting of two stages, namely
Exploration Mining Business License and Mining Production Operation License;

b. Mining Permit for the People (IPR) The permission to carry out mining business within the mining area with limited area and investment. The mining activities of the people can only be done on the following mines: 5. Metal mineral mining; 6. Non-metallic mineral mining; 7. Mining of rocks; and / or 8 . Coal mining. IPR may be provided to individuals of at most one hectare; community groups at most five hectares; and / or cooperatives at most ten hectares. The IPR period is five years and can be extended.

c. Special Mining Business License (IUPK) is a license to carry out mining business in a special mining business permit area.

Same as IUP, IUPK also consists of two licensing stages namely IUPK exploration and production operation IUPK. The advantages of IUPK are the holders who find other minerals in the area of production business licenses are managed to given priority to work on them. The mineral and coal law provides unified arrangements and systems for mining of minerals and coal, including in the case of a system of granting the right to conduct mining operations. Under the old mineral and coal law and clarified by various decisions of the President and Ministerial Decrees that have authority in the field of mining, the right granting system for mining entrepreneurs is Mining KK for mineral mining and PKP2B for coal min ing. Under the mineral and coal act, the system of granting rights to mineral and coal mining is equated through the IUP grant system. The IUP system also eliminates the distinction between domestic investors and foreign investors in the mining sector. Relation with the dispute set out in the mineral and coal act the settlement of disputes in the form of permits in this law shall enter into the competence of the state administrative court under Article 1 number 10 of Law Number 51 Year 2009 on the Second Amendment to Law Number 5 Year 1986 pertaining to the Administrative Court State Enterprises jo. Law Number 9 Year 2004 regarding the Amendment of Law Number 5 Year 1986 concerning State Adminis trative Court jo. Law Nu mber 5 of 1986 (the "Administrative Law"):

Sengketa Tata Usaha Negara adalah sengketa yang timbul dalam bidang Tata Usaha Negara antara orang atau badan hukum perdata dengan Badan atau Pejabat Tata Usaha Negara, baik di pusat maupun di daerah, sebagai akibat dikeluarkannya Keputusan Tata Usaha Negara (KTUN), termasuk sengketa kepegawaian berdasarkan peraturan perundang-undangan yang berlaku.

Then Elucidation of article 1 number (4)

Istilah "sengketa" yang dimaksudkan di sini mempunyai arti khusus sesuai dengan fungsi Peradilan Tata Usaha Negara yaitu menilai perbedaan pendapat mengenai penerapan hukum. Badan atau Pejabat Tata Usaha Negara dalam mengambil keputusan pada dasarnya mengemban kepentingan umum dan masyarakat, tetapi dalam hal atau kasus tertentu dapat saja keputusan itu dirasakan mengakibatkan kerugian bagi orang atau badan hukum perdata tertentu, dalam asas Hukum Tata Usaha Negara kepada yang bersangkutan harus diberikan kesempatan untuk mengajukan gugatan Pengadilan. 
On the basis of this formula can be put forward that must be met for the existence of state administration dispute, there are :

a. There is must be a difference of opinion about a right or a duty. These rights and obligations are the result of the application of certain laws. This means that the dispute arises because there has been an application of law by the state adminis trative officer.

b. The dispute lies in the field of state administration. The meaning of state administration is a state administration that performs functions to administer government affairs both at the center and in the regions;

c. The subject of dis pute is an individual or a civil legal entity as the Plaintiff and the State Administration Officer or Agency as the Defendant;

d. The dispute arose because of the enactment of the State Adminis trative Decree.

The TUN dispute contains 2 (two) elements, there are ; subject to dispute and object disputes. The subject of the dispute is a civil person or legal entity with the Board or State Administration Officer and the object of dispute in the form of KTUN. Thus, KTUN is the basis of the birth of TUN dispute, without the existence of KTUN there will be no TUN Dispute, so this KTUN is a sine quanon conditio for the emergence of TUN dispute. What is a KTUN?

In the case of the granting and revocation of the Mining Business License is set forth in the form of Decision of the State Administrative Officer which is meant by the state admin istrative decision in the provision of Article 1 point 9 of Law number 51 of 2009 on the Second Amendment of Law number 5 of 1986 on the State Administrative Court, states:

Keputusan Tata Usaha Negara adalah suatu penetapan tertulis yang dikeluarkan oleh Badan atau Pejabat Tata Usaha Negara yang berdasarkan peraturan perundangundangan yang berlaku, yang bersifat Konkret, individual dan final yang menimbulkan akibat hukum bagi seseorang atau badan hukumperdat

Thus, is suing or revoking the government mining permit it can be judged by the Court, meaning that any actions / actions of the government can be sued before the Court, while the absolute competence of the State Administrative Court has the following characteristics:

1. The parties to the dispute are persons or Civil Law Bodies with the State Administration Officers or Officials;

2. The object of the dispute is the Adminis trative Decree of the State, namely a written Declaration issued by the Board or Adminis trative Officer of the State;

3. The decision made as the object of the dispute contains the act of state adminis trative law;

4. The decisions which the object of the dispute is concrete, individual and final shall have legal consequences for a person or a civil law entity.

Although the state administrative court is a court that has absolute authority in handling mining licensing disputes, there are some disadvantages that, although legally, the beshicking holder who feels impaired his right may sue the concerned official through the Administrative Court. The state, however, until now the decision of the state admin istrative court is doubtful about the effectiveness of its implementation, mainly because this ruling is only administrative with limited amount of compensation, this compensation does not cover the replacement of losses suffered by the holder of mining permits on the decision of officials State Administration that is detrimental to its business activities.

\section{SUMMARY}

\section{A. Conclusion}

Starting from the point of view continued with the theoretical explanation and based on legal analysis as described earlier, the provision of dispute resolution on the implementation of mining permits as regulated in the mining mineral and coal act is the object of dispute in the state administrative court, but there are records concerning the settlement of mining permit disputes in the administrative court state because the mining sector is a capital-intensive and time-bound, very sensitive business so that there is little disruption will cause a huge loss for investors, the follow-up of the PTUN ruling becomes an obstacle because the implementation is still not maximally implemented by officials state administration, and then to claim significant losses, the holder of a perceived disadvantage still has to file a civil lawsuit against the Government on the basis of an unlawful act which again is also not very effective considering the time tu a long solution and a large cost.

\section{B. Suggestions}

1. Revision of the mining mineral and coal law, with the existence of various problems related to this law, especially regarding the settlement of mining disputes, the authors suggest that policy makers can immediately revise the mining mineral and coal act related to the settlement of mining disputes, should be given an adequate formulation and explanation or implementation regulations such as in the form of government regulations that specifically regulate the implementation of dispute settlement on mining permits.

2. The Supreme Court together with the government should seek to make the state administrative court decision workable by the government so that the interests of justice seekers can be protected.

3. Special training for state administrative courts judges to handle mining licensing disputes.

\section{REFERENCES}

[1] Indonesia termasuk negara type Werlfare State, hal ini terbukti dari : Pertama, salah satu sila dari Pancasila sebagai dasar falsafah negara ( sila ke lima) adalah Keadilan Sosial. Kedua, dalam Pembukaan UUD 1945 .

[2] S.F. Marbun, Peradilan Administrasi Negara dan Upaya Administrasi di Indonesia, (Yogyakarta: Liberty, 1997).

[3] Philipus M. Hadjon, Perlindungan Hukum Bagi Rakyat di Indonesia, (Surabaya: PT. Bina Ilmu, 1987).

[4] Paulus Effendie Lotulung, Beberapa Sistem Tentang Kontrol Segi Hukum Terhadap Pemerintah, (Jakarta: PT. Bhuana Ilmu Populer, 1986)

[5] Sjachran Basah, Perlindungan Hukum Terhadap Sikap Tindak Administrasi Negara, (Bandung: Alumni, 1992).

[6] Baharuddin Lopa dan Andi Hamzah, Mengenal Peradilan Tata Usaha Negara, (Jakarta: Sinar Grafika, 1993). 
[7] Mudzakir NFN, Metode Penelitian Hukum, Yogyakarta: (Yogyakarta: Program Magister (S2) Ilmu Hukum, Universitas Islam Indonesia,n.d.).

[8] Peter Mahmud Marzuki, Penelitian Hukum (Surabaya: Kencana Prenada Media Group, 2005).
[9] Muchsan, Sistem Pengawasan Terhadap Perbuat an Aparat Pemerint ah Dan Peradilan Tata Usaha Negara di Indonesia, (Yogyakarta: Liberty, 1992) 